\title{
The canonical UPF1-dependent nonsense-mediated mRNA decay is inhibited in transcripts carrying a short open reading frame independent of sequence context
}

\author{
ANA LUÍSA SILVA, ${ }^{1}$ FRANCISCO J.C. PEREIRA, ${ }^{1}$ ANA MORGADO ${ }^{1}{ }^{~ J I A N ~ K O N G, ~}{ }^{2}$ RUTE MARTINS, ${ }^{1}$ \\ PAULA FAUSTINO, ${ }^{1}$ STEPHEN A. LIEBHABER, ${ }^{2}$ and LUÍSA ROMÃO ${ }^{\mathbf{1}}$ \\ ${ }^{1}$ Centro de Genética Humana, Instituto Nacional de Saúde Dr. Ricardo Jorge, 1649-016 Lisboa, Portugal \\ ${ }^{2}$ Department of Genetics and Department of Medicine, University of Pennsylvania, Philadelphia, Pennsylvania 19104, USA
}

\begin{abstract}
Nonsense-mediated mRNA decay (NMD) is a surveillance mechanism that degrades mRNAs carrying premature translation termination codons. Generally, NMD is elicited if translation terminates $>50-54$ nucleotides (nt) upstream of an exon-exon junction. We have previously reported that human $\beta$-globin mRNAs carrying 5 '-proximal nonsense mutations (e.g., $\beta 15$ ) accumulate to normal levels, suggesting an exception to the "50-54-nt boundary rule." In the present report, we demonstrate that the strength of the UPF1-dependent NMD of mutant $\beta$-globin mRNAs is specifically determined by the proximity of the nonsense codon to the initiation AUG. This conclusion is supported by a parallel effect of the short ORF size on NMD of nonsense-containing $\alpha$-globin mRNAs. To determine whether the short-ORF effect on NMD response is conserved in heterologous transcripts, we assessed its effects on a set of $\beta$-globin/triosephosphate isomerase (TPI) hybrid mRNAs and on the TPI mRNA. Our data support the conclusion that nonsense mutations resulting in a short ORF are able to circumvent the full activity of the canonical UPF1-dependent NMD pathway.
\end{abstract}

Keywords: nonsense-mediated mRNA decay (NMD); UPF1-dependent NMD; 50-54-nt boundary rule; short open reading frame $(\mathrm{ORF})$; translation reinitiation

\section{INTRODUCTION}

Post-transcriptional quality control of eukaryotic gene expression is critical to proper cell function. Nonsensemediated mRNA decay (NMD) is an example of a posttranscriptional mechanism used to survey mRNA structure. By recognizing and degrading abnormal transcripts that prematurely terminate translation, NMD prevents the production of truncated proteins that could have a dominant-negative effect on the cell. NMD may also function in post-transcriptional control of selected physiologic transcripts with NMD features, such as mRNAs with upstream open reading frames (uORFs) and mRNAs containing an intron within the $3^{\prime}$-untranslated region ( $3^{\prime}$-UTR) (Mendell et al. 2004; Wittmann et al. 2006).

NMD targeting depends on the interaction of signals generated by transcript splicing and mRNA translation.

Reprint requests to: Luísa Romão, Centro de Genética Humana, Instituto Nacional de Saúde Dr. Ricardo Jorge, Av. Padre Cruz, 1649016 Lisboa, Portugal; e-mail: luisa.romao@insa.min-saude.pt; fax: (351) 21 7526410 .

Article published online ahead of print. Article and publication date are at http://www.rnajournal.org/cgi/doi/10.1261/rna.201406.
This combination of determinants allows the translating ribosome to "recognize" where the termination codon is positioned relative to exon-exon junctions (Maquat 2004, 2005; Lejeune and Maquat 2005). In mammalian cells, an exon-junction protein complex (EJC) is deposited on the transcript during nuclear transcript splicing at a position 20-24 nucleotides (nt) upstream of each exon-exon junction (Le Hir et al. 2001). According to present models, translating ribosomes displace EJCs from the ORF during the "pioneer" round of translation (Ishigaki et al. 2001; Lejeune et al. 2002). If an mRNA contains a premature termination codon located $>50-54$ nt upstream of the last exon-exon junction, the ribosome will not extend far enough into the mRNA to displace all the EJCs, and one or more will be retained on the mRNA and trigger NMD. The NMD-linked destabilization mechanism appears to involve the recruitment and phosphorylation of UPF1 and its interaction both with the EJC and with the translation termination release factors eRF1 and eRF3 (Le Hir et al. 2000; Fribourg et al. 2003; Gehring et al. 2003; Lau et al. 2003; Kashima et al. 2006; Kunz et al. 2006). Thus, the UPF1 protein provides an essential link in the NMD pathway (Kashima et al. 2006). Consistent with this model, 
inhibition of UPF1 expression in a cell inhibits the NMD response (Sun et al. 1998; Mendell et al. 2002).

According to the literature cited above, nonsense codons elicit NMD if they are followed by at least one exon-exon junction located $>50-54 \mathrm{nt}$ downstream (Thermann et al. 1998; Zhang et al. 1998). Nevertheless, some exceptions to the "50-54-nt boundary rule" have been reported. These exceptions may each reflect different mechanisms that blunt or circumvent NMD. One exception has been reported in the context of the triosephosphate isomerase (TPI) transcript. Zhang and Maquat (1997) have shown that TPI transcripts nonsense mutated at codon 1,2 , or 10 circumvent NMD and that this NMD resistance results from translation reinitiation at codon 14Met (Zhang and Maquat 1997). In fact, it was proven that in these nonsense transcripts, translation reinitiation occurs, downstream from the nonsense codon, with high efficiency at $14 \mathrm{Met}$ (Zhang and Maquat 1997; Poyry et al. 2004). More recently, Stockklausner et al. (2006) have studied NMD for the human thrombopoietin (TPO) mRNA. This mRNA contains seven uORFs, all terminating $>50$ nt upstream of the last exon-exon junction (Ghilardi and Skoda 1999), and yet seems to avoid NMD. While these authors demonstrate that elongation of the $3^{\prime}$-most uORF from 27 to 40 codons decreases mRNA steady-state levels, this decrease did not appear to reflect the canonical human UPF1-dependent NMD pathway, and the underlying mechanism remains undefined (Stockklausner et al. 2006).

Studies from our laboratory indicate that human $\beta$ globin mRNAs containing nonsense mutations in the $5^{\prime}$ region of exon 1 accumulate to levels similar to those of normal $\beta$-globin transcripts (Romão et al. 2000). This resistance to NMD is erythroid independent and independent of promoter identity, and does not reflect translation reinitiation, abnormal RNA splicing, or impaired translation (Inácio et al. 2004). Instead, the observed NMD resistance appears to reflect the close proximity of the nonsense codon to an upstream determinant (Inácio et al. 2004). In this study, we demonstrate that the critical parameter for NMD inhibition in this setting is the proximity of the nonsense codon to the translation initiation codon. Our data further indicate that this AUG-proximity effect appears to be an attribute of the canonical UPF1dependent NMD response that is independent of the transcript identity and sequence context.

\section{RESULTS}

\section{A critical proximity of the nonsense codon to the translation initiation codon inhibits the NMD response}

We have previously reported that human $\beta$-globin mRNAs carrying nonsense mutations near the initiation codon have a markedly blunted NMD response and are expressed at levels approaching those of the wild-type $\beta$-globin mRNA. Since these nonsense codons are situated well $5^{\prime}$ to the exon junctions of the $\beta$-globin transcript, they constitute an exception to the "50-54-nt boundary rule." Thus, $\beta$-globin mRNAs carrying the nonsense mutation at codon $15(\beta 15)$ escape NMD, while transcripts carrying a nonsense mutation at codon 39 ( $\beta 39)$ are effectively degraded via the NMD pathway (Romão et al. 2000). We have also shown that insertion of a 72-base-pair (bp) fragment between the AUG and the $\beta 15$ nonsense mutation, which moves the nonsense codon to position 39, renders the mRNA NMD sensitive (Inácio et al. 2004). In this study, our first aim was to determine whether the blunting of NMD by this 72-bp sequence insertion reflected an alteration in the proximity of the nonsense codon to the initiation AUG or to a $5^{\prime}$ UTR determinant such as the cap. This was addressed by inserting the same 72-bp fragment into the $5^{\prime}$-UTR (at 21 bp upstream of the AUG) of the $\beta \mathrm{WT}, \beta 15$, and $\beta 39$ genes and measuring the impact of each insertion on mRNA expression. This set of insertions created the $\beta$ WTins5' UTR, $\beta 15$ ins5'UTR, and $\beta 39$ ins5'UTR genes, respectively (Fig. 1A). Each gene was transfected into HeLa cells, and the encoded mRNAs were quantified $20 \mathrm{~h}$ post-transfection (see Materials and Methods). Each expression level was normalized to the level of Puro ${ }^{r}$ mRNA encoded from the puromycin-resistance gene cloned into the $\beta$-globin expression vector. Results from three independent experiments revealed that the nonsense-containing $\beta 15$ ins5'UTR gene was expressed to the same level as the $\beta$ WTins $5{ }^{\prime}$ UTR gene and that the 72-bp insertion within the $5^{\prime}$-UTR had no adverse effect on the expression of either mRNA (Fig. 1B). As expected, expression of the NMD-sensitive $\beta 39$ mRNA was markedly repressed, and the $5^{\prime}$-UTR insertion ( $\beta 39$ ins5'UTR construct) (Fig. 1 ) had no effect on the $\beta 39$ gene expression level. These results illustrate that insertion of a 72-bp spacer within the 5'-UTR fails to alter the expression of the NMD-competent and NMD-resistant mRNAs. In addition, since mammalian NMD is dependent on mRNA translation, and the $5^{\prime}$-UTR insertion failed to stabilize the $\beta 39$ mRNA, we also conclude that the stability of the $\beta 15$ ins5'UTR mRNA did not reflect inhibition of translation by the 72-nt insertion. This conclusion was further validated assessing the translation of the $\beta$ WTins5' UTR mRNA ( $\beta W T$ ) (Fig. 1C). The translation efficacy of the $\beta$ WTins5'UTR mRNA was $80 \%$ of the normal control (Fig. 1C). Therefore, the 72-bp spacer does not appear to result in a major alteration in translation and does not impair NMD. Thus, the $5^{\prime}$-UTR 72-bp insertion fails to destabilize the $\beta 15$ mRNA, while insertion of the same sequence between the $\beta 15$ nonsense mutation and the AUG, increasing the ORF from 15 to 39 codons $[\beta 15(15: 39)$ mRNA], markedly decreases mRNA accumulation to a level comparable to that of $\beta 39$ mRNA (24\% and $18 \%$ of $\beta \mathrm{WT}$, respectively) (Fig. 1B; Inácio et al. 2004). These results substantiate the role for AUG-proximity in the NMD mechanism. 
A
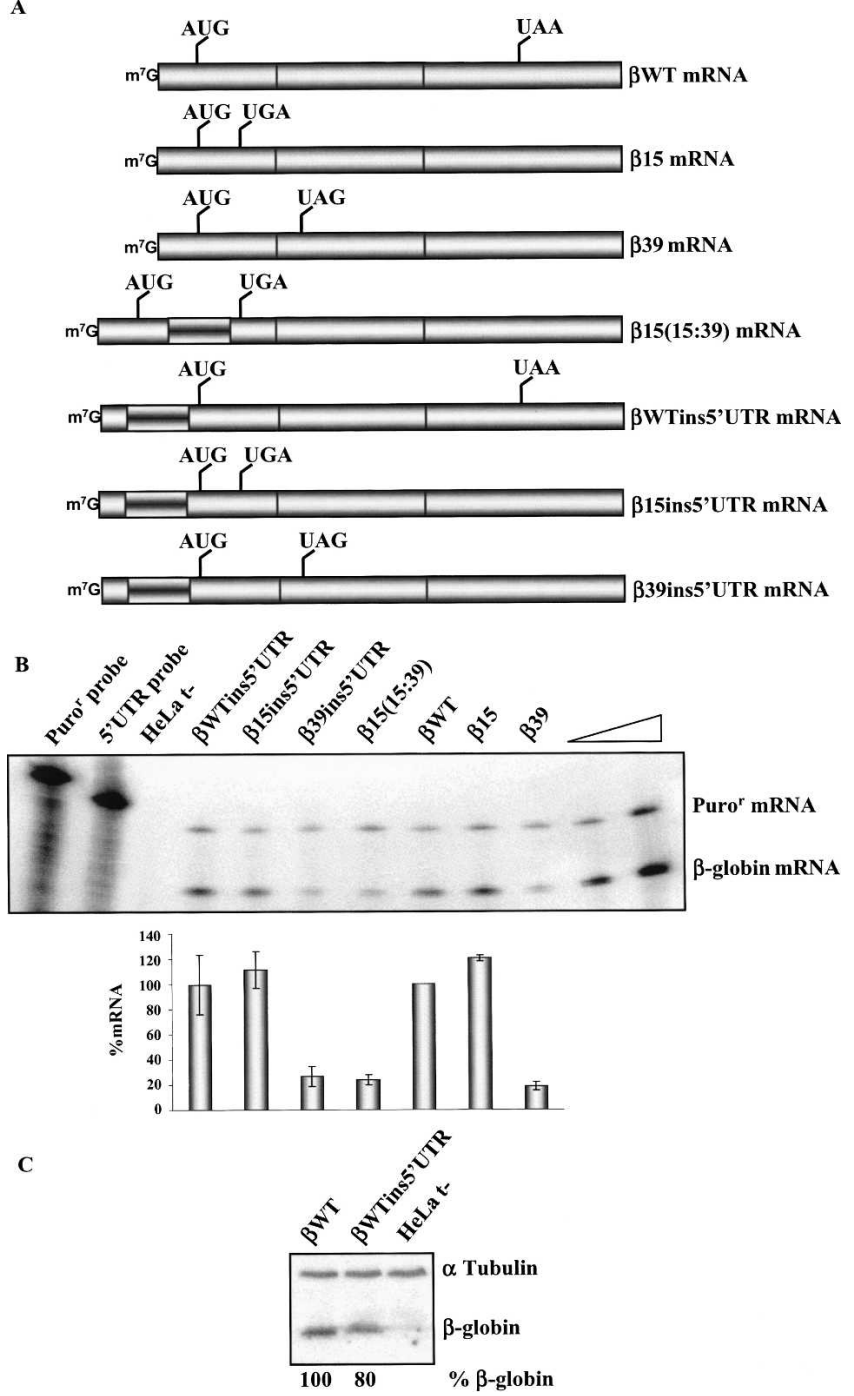

FIGURE 1. The proximity of the nonsense codon to the AUG, rather than the distance to a putative $5^{\prime}$-UTR determinant, inhibits mRNA decay. (A) Schematic representation of the studied human $\beta$-globin mRNAs. The position of initiation and termination (native or premature) codons is represented. The inverted-shadowed box represents the spacer insertion. The name of each transcript is indicated on the right. (B) Representative RPA of RNA isolated from HeLa cells untransfected $(\mathrm{t}-)$ or transfected with constructs specified above each lane. Increasing amounts of RNA (indicated by a triangle) from HeLa cells transfected with the $\beta \mathrm{WT}$ gene were also analyzed to demonstrate that the experimental RPA was carried out in probe excess; the amount of each of the input riboprobes used per analysis is also shown. The positions of the human $\beta$-globin or puromycin-resistance (Puro $\left.{ }^{r}\right)$ mRNAs are indicated on the right of the autoradiograph. Levels of human $\beta$-globin mRNA were normalized relatively to Puro ${ }^{r}$ and then compared to wild type (WT). Average values from five independent experiments and standard deviations are plotted below the autoradiograph. (C) Western blot analysis of the HeLa cells extracts untransfected $(\mathrm{t}-)$ or transfected with the constructs specified above each lane. Immunoblotting was performed using a human $\beta$-globin-specific antibody and a $\alpha$-tubulin-specific antibody to control for variations in protein loading.

\section{Increasing the ORF length of the $\beta$-globin transcripts from 15 to 39 codons activates UPF1-dependent NMD}

We next sought to demonstrate that the destabilization observed by increasing the ORF length of the $\beta$-globin transcripts from 15 to 39 codons was due to activation of the UPF1-dependent decay pathway. We analyzed the steady-state levels of $\beta$-globin nonsense-mutated mRNAs in HeLa cells depleted of human UPF1 protein by RNA interference (RNAi). UPF1 short interfering (si)RNA, or nonspecific control (Luciferase; Luc) siRNA, was cotransfected with each of three $\beta$-globin genes: $\beta W T, \beta 39$, and $\beta 15(15: 39)$. Two days after transfection, a Western blot analysis showed a decrease of $87 \%$ in UPF1 protein expression induced by siRNA [Fig. 2A, lane $\beta 15(15: 39)+U P F 1$ siRNA versus lane $\beta 15(15: 39)+$ Luc siRNA]. At this level of UPF1 down-regulation, mRNA was quantified by RPA, relatively to $\beta W T$. In untreated cells, the $\beta 15(15: 39)$ mRNA accumulated to about the same level as $\beta 39$ mRNA ( $21 \%$ and $17 \%$ of $\beta$ WT mRNA, respectively), consistent with both mRNAs being targeted by NMD (Inácio et al. 2004). The same expression levels for $\beta 39$ and $\beta 15(15: 39)$ were measured in cells treated with the control siRNA (Luc siRNA; $14 \%$ and $15 \%$ of the $\beta W T$ mRNA, respectively) (Fig. 2B). In contrast, depletion of UPF1 resulted in a 3.5fold increase in the abundance of $\beta 15(15: 39)$ mRNA and a 2.6-fold increase in $\beta 39$ mRNA (Fig. 2B). These data confirm that the increase of $\beta 15(15: 39)$ mRNA expression reflects the UPF1 depletion on the NMD pathway. These data further support the role of the short ORF (i.e., the AUG-proximity effect) in the inhibition of the UPF1dependent NMD mechanism.

\section{The effect of a short ORF on NMD is also observed in human $\alpha$-globin transcripts}

To determine the generality of our findings, we next tested the relationship between NMD and the ORF size in additional mRNAs. We first asked whether $\alpha$-globin mRNAs show parallel NMD profiles to that seen for $\beta$-globin mRNA. Nonsense mutations at codons 4 (CCT $\rightarrow$ TAG), $14(\mathrm{TGG} \rightarrow \mathrm{TAG}), 16(\mathrm{AAG} \rightarrow \mathrm{TAA})$, or $40(\mathrm{AAG} \rightarrow \mathrm{TAG})$ $(\alpha 4, \alpha 14, \alpha 16$, or $\alpha 40$ genes, respectively) were introduced into the full-length $\alpha$-globin gene cloned in the mammalian expression vector pTRE- $\alpha$ WT (see Materials and Methods). HeLa cells were then transfected with each plasmid, and the level of the encoded mRNA was determined and normalized (see Materials and Methods). The results reveal that $\alpha$-globin mRNAs carrying nonsense mutations at codons 4,14 , or 16 accumulate to steady-state levels comparable to wild type $(85 \%, 92 \%$, and $95 \%$ of $\alpha \mathrm{WT}$, respectively) (Fig. 3A). In contrast, expression of the $\alpha 40$ mRNA was repressed to $25 \%$ of $\alpha \mathrm{WT}$ levels, compatible 


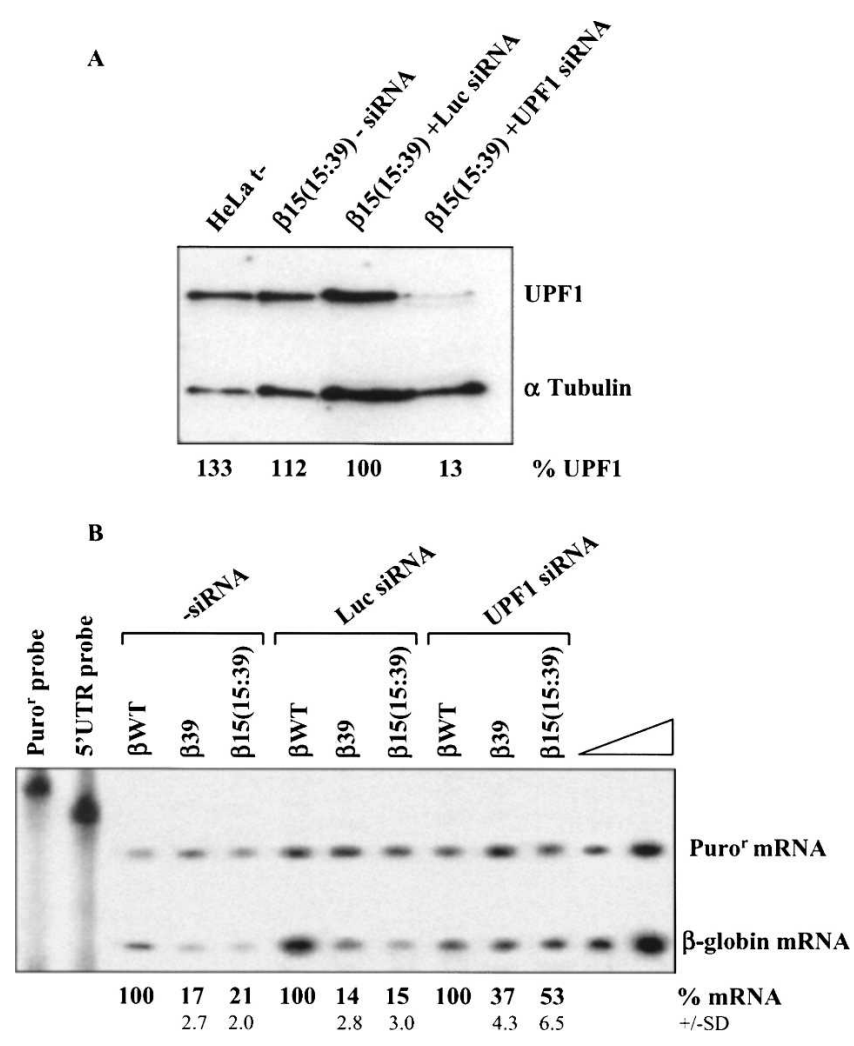

FIGURE 2. Down-regulating human UPF1 protein results in an upregulation of the $\beta 15(15: 39)$ transcripts. HeLa cells were transiently cotransfected with synthetic small-interfering RNA (siRNA) duplexes directed to human UPF1 or to a non-endogenous target (Luciferase; Luc) used as control, and plasmids with the $\beta$-globin gene variants [normal ( $\beta \mathrm{WT}), \beta 39$, and $\beta 15(15: 39)$; plasmid also contains the puromycin resistance $\left(\right.$ Puro $\left.^{\mathrm{r}}\right)$ gene]; $(\mathrm{t}-)$ untransfected cells. About $24 \mathrm{~h}$ after siRNA treatment, cells were transfected with the $\beta$-globin constructs specified above each lane. Two days after transfection, protein and RNA were isolated. (A) Western blot analysis of the HeLa cell extracts transfected with human UPF1 siRNA. Immunoblotting was performed using a human UPF1-specific antibody and an $\alpha$ tubulin-specific antibody to control for variations in protein loading. (B) Representative RPA to quantify the level of human $\beta$-globin transcript, normalized to the level of puromycin-resistance $\left(\right.$ Puro $\left.^{r}\right)$ mRNA. Increasing amounts of RNA (indicated by a triangle) from HeLa cells transfected with $\beta W T$ gene were also analyzed to demonstrate that the experimental RPA was carried out in probe excess; the amount of each of the input riboprobes used per analysis is also shown. Levels of $\beta 39$ and $\beta 15(15: 39)$ transcripts were compared to $\beta$ WT mRNA levels (defined as 100\%) in the absence (-siRNA) or in the presence of each siRNA. The mRNA percentage average values and standard deviations from three independent experiments are indicated at the bottom.

with a full NMD response (Pereira et al. 2006). Thus, as was the case with the $\beta$-globin mRNA, the $\alpha$-globin mRNA expression levels corresponded to the AUG-proximity of the nonsense codons.

To confirm that the stability of the $\alpha$-globin mRNAs with AUG-proximal nonsense mutations is maintained, we measured the absolute half-life of $\alpha 16$ mRNA and compared it to the $\alpha \mathrm{WT}$ mRNA and to the NMD-sensitive $\alpha 40$
mRNA. Each of the three genes was cloned behind a tetracycline (tet) controlled promoter and transfected into a MEL cell line that stably expresses the tet-transcriptional transactivator (MEL/tTA cells). The cells were then transcriptionally pulsed for $4 \mathrm{~h}$ with each $\alpha$-globin mRNA (see Materials and Methods) (Kong et al. 2003), and the rate of $\alpha$-globin mRNA decay was measured over time (Fig. 3B). Data from four independent experiments show that the half-life of normal $\alpha$-globin mRNA is $11.5 \mathrm{~h}$. In contrast, the half-life of the $\alpha 40$ is $2.0 \mathrm{~h}$, consistent with a full sensitivity to NMD, as previously reported (Pereira et al. 2006). The half-life of $\alpha 16$ mRNA (7.7 h) is intermediate to the $\alpha \mathrm{WT}$ and $\alpha 40$ mRNAs (Fig. 3B). The observation that the $\alpha 16$ mRNA had a half-life almost fourfold higher than the $\alpha 40$ mRNA confirms that the AUG-proximal nonsensemutated $\alpha$-globin mRNAs carrying a short ORF escape the full impact of NMD.

Translation reinitiation downstream from the nonsense codon can blunt the NMD effect (Zhang and Maquat 1997). If the NMD resistance observed on the $\alpha$-globin mRNAs with 5 '-proximal nonsense mutations reflected translation reinitiation, then removing initiation codons $3^{\prime}$ to the nonsense mutation should restore NMD and destabilize the mRNA. To test this effect in the context of the $\alpha$-globin mRNA, the AUG codons at positions 32 and 76 (in frame) were mutated to ACG (threonine) within the $\alpha \mathrm{WT}, \alpha 14$, and $\alpha 40$ genes. The 32Met and 76Met are located at $201 \mathrm{nt}$ and $69 \mathrm{nt}$ upstream of the last exon-exon junction, respectively. An additional out-of-frame AUG codon at position 24/25 was not tested because the potential reinitiation at this site would not extend far enough to displace the last EJC (the 24/25Met is in frame with a stop codon at position 48/49) and NMD would thus be triggered, as previously described (Pereira et al. 2006). The 32Met and 76Met AUG-to-ACG conversions created $\alpha \mathrm{WT}-32-76 \mathrm{Met} \rightarrow \mathrm{Thr}, \alpha 14-32-76 \mathrm{Met} \rightarrow \mathrm{Thr}$ and $\alpha 40$ $32-76 \mathrm{Met} \rightarrow$ Thr genes. Expression of each of these genes was analyzed in HeLa cells (Fig. 3C). The $\alpha 40-32-$ $76 \mathrm{Met} \rightarrow \mathrm{Thr}$ mRNA was expressed at the same level as $\alpha 40$ mRNA (23\% of $\alpha \mathrm{WT})$, consistent with both being fully committed to NMD. On the other hand, $\alpha 14-32-$ $76 \mathrm{Met} \rightarrow$ Thr transcripts accumulate at $\sim 71 \%$ of $\alpha \mathrm{WT}$, and at $\sim 80 \%$ of $\alpha 14$ mRNA. Of note, expression of the $\alpha 14$ mRNA with the double mutation remains well above that of the $\alpha 40$ mRNA. Thus, we find that blocking potential translation reinitiation sites results in a minimal decrease in $\alpha 14$ mRNA expression. These results, in combination with our prior studies (Inácio et al. 2004), show that for both $\alpha$ globin and $\beta$-globin mRNAs, the presence of the nonsense codon in close proximity to the AUG markedly reduces the effect of NMD on the mutant mRNA. In both cases, the effect of the short ORF appears to be the major determinant for NMD inhibition. 


\section{The effect of a short ORF on NMD is conserved in heterologous transcripts}

A well-documented exception to the " $50-54-n t$ boundary rule" is represented by TPI mRNAs with AUG-proximal nonsense mutations at codons 1, 2, or 10 (Zhang and Maquat 1997). The NMD resistance in these cases has been shown to reflect translation reinitiation; these nonsense codons elicit NMD when translation reinitiation is inhibited at codon 14 (Zhang and Maquat 1997). Therefore, early nonsense codons on different transcripts and in different sequence contexts may manifest NMD resistance based on different mechanisms. To further explore this issue, we investigated the involvement of the AUG-proximity effect in a set of nonsense-mutated TPI/ $\beta$ globin and $\beta$-globin/TPI hybrid genes (Figs. 4, 5). These genes were transiently transfected into HeLa cells, and the levels of the encoded mRNAs were quantified and normalized relative to the Puro ${ }^{\mathrm{r}}$ mRNA and to the expression level of the corresponding nonsense-free genes (Figs. 4, 5).

The first chimeric mRNA to be assessed contains a fusion between the $5^{\prime}$ terminus of the TPI mRNA up to codon 9 with the $\beta 15$ mRNA beginning with the nonsense UGA at codon 15 (Fig. $4 \mathrm{~A})$. This TPI/ $\beta 15$ mRNA is expressed at a level comparable to the control TPI/ $\beta W T$ chimeric mRNA that lacks the nonsense mutation. This comparison demonstrates that the TPI/ $\beta 15$ mRNA is fully resistant to NMD. To investigate whether this resistance is due to translation reinitiation, all potential reinitiating AUGs that could inhibit NMD were inactivated in the TPI/ $\beta 15$ and TPI/ $\beta$ WT genes (Fig. 4A). These AUG codons occur at positions $55,63 / 64$, and 73/74 (located at 149, 124, and $94 \mathrm{nt}$ upstream of the last exon-exon junction, respectively). The normalized expression level of the TPI/ $\beta 15-55-63 /$ 64-73/74 mRNA was similar to the control TPI/ $\beta$ WT-55-63/64-73/74 mRNA (Fig. 4B). Thus, elimination of all the potential translation reinitiation sites failed to destabilize the TPI/ $\beta 15$ mRNA. These data demonstrate that the AUGproximity effect is sufficient to fully inhibit NMD in the context of a heterologous ORF sequence.

We next altered the context of the nonsense codon in a reciprocal manner by constructing hybrid $\beta$-globin/TPI genes in which the $5^{\prime}$ terminus of the $\beta 15$ or $\beta 39$ globin mRNAs up to and including the respective nonsense codons or the corresponding normal codons were fused to the TPI mRNA beginning at codon 11 (Fig. 5A). These genes were transfected into HeLa cells, and the impact of the $\beta 15$ and $\beta 39$ nonsense codons in the chimeric sequence context was assessed. The $\beta 39 /$ TPI mRNA accumulates at $32 \%$ of the corresponding wild-type $\beta$ WT39/TPI mRNA control (Fig. $5 \mathrm{~B})$. This repressed level of expression is identical to that of the $\beta 39$ mRNA (Fig. 5B), showing that the $\beta 39 /$ TPI mRNA is fully committed to NMD. Introducing a missense mutation at TPI codon 14 of the $\beta 39 /$ TPI gene

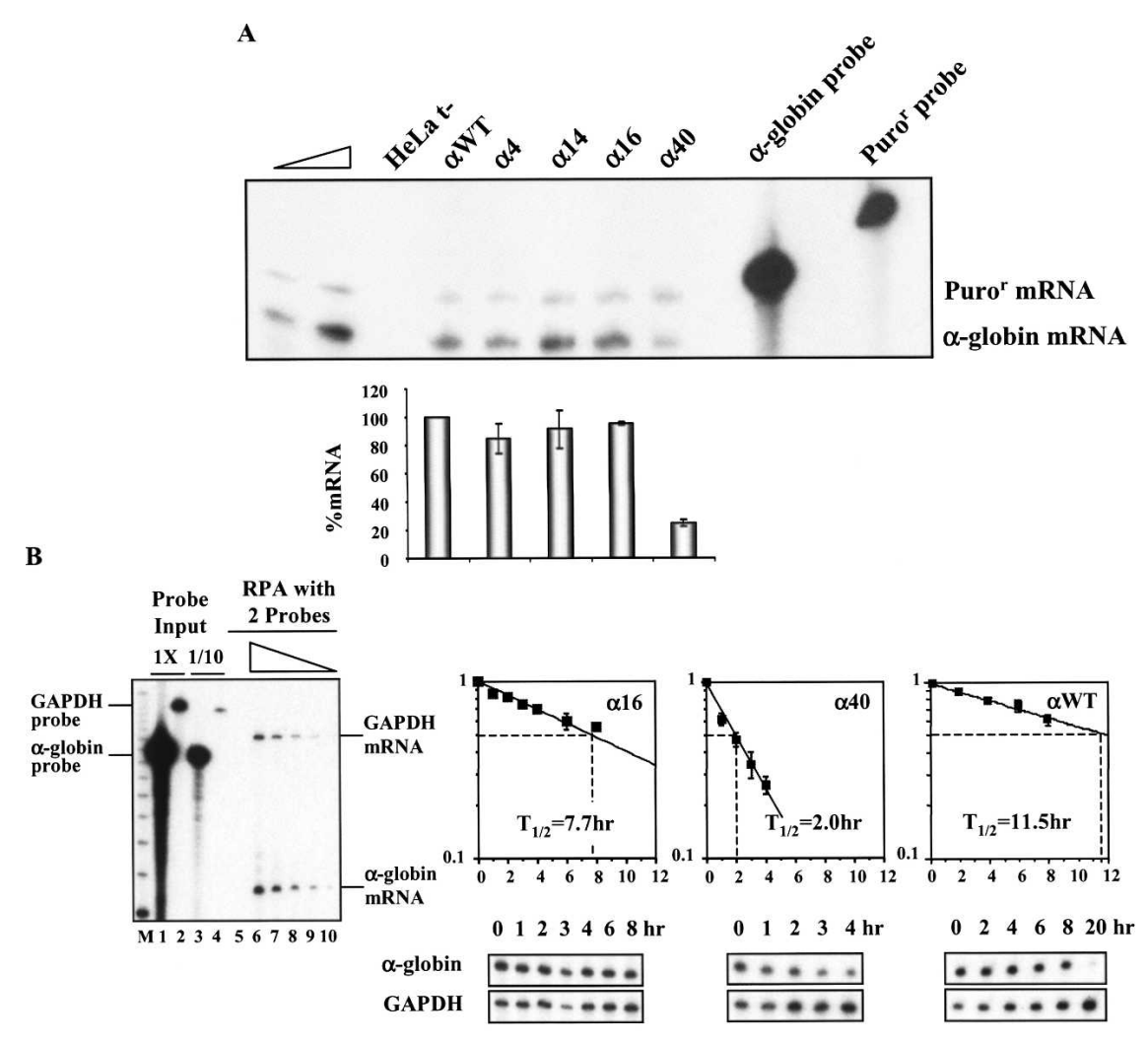

C
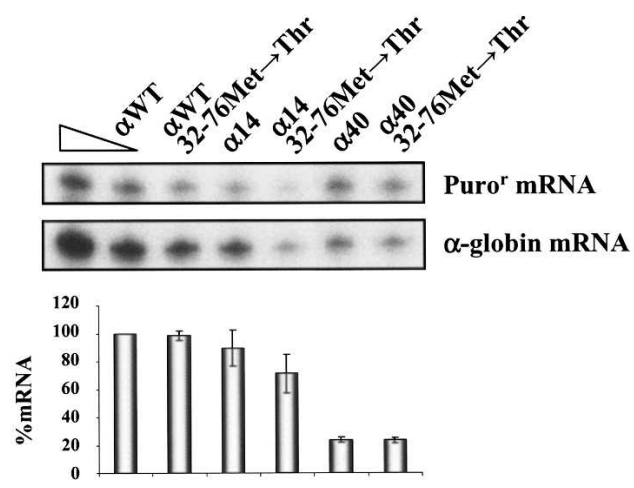

FIGURE 3. (Legend on next page) 
$(\beta 39 / \mathrm{TPI}-14 \mathrm{Met} \rightarrow$ Val construct) to block potential translation reinitiation did not alter the accumulation of the B39/TPI mRNA (Fig. 5B). In contrast, the mRNA generated by shortening the ORF length from 39 to 15 codons in the same chimeric mRNA context ( $\beta 15 / \mathrm{TPI}$ mRNA) is expressed at levels equivalent to those of the $\beta$ WT15/TPI mRNA (Fig. 5B). These results indicate that NMD of $\beta 15 /$ TPI mRNA is fully inhibited. Based on the results published by Zhang and Maquat (1997), we next investigated if the observed $\beta 15 /$ TPI mRNA NMD resistance could reflect translation reinitiation at codon 14 of TPI mRNA, as this has been previously shown to be an effective reinitiation site (Zhang and Maquat 1997; Poyry et al. 2004). A Met $\rightarrow$ Val substitution at codon 14 of the TPI was introduced into the $\beta 15 /$ TPI gene. It must be noted that this amino acid substitution leaves intact the TPI sequence (three codons) between the nonsense codon and 14Met, which parallels the condition of the TPI10Ter-14Met $\rightarrow$ Val construct studied by Zhang and Maquat (1997). Expression in HeLa cells showed that $\beta 15 /$ TPI-14Met $\rightarrow$ Val mRNA accumulates at $\sim 67 \%$ of the $\beta$ WT15/TPI mRNA level (Fig. $5 \mathrm{~B})$. Thus, if translation reinitiation is abrogated at codon 14 of TPI, the $\beta 15 / \mathrm{TPI}-14 \mathrm{Met} \rightarrow$ Val mRNA accumulation is partially repressed. This result is consistent with the analysis of the $\alpha 14$ transcript (Fig. 3C). Taken together, these results illustrate that while translation reinitiation can play a role in NMD inhibition of $\beta 15 / T P I$ transcripts, this is only partially responsible for the resistance of this mRNA to NMD because the $\beta 15 /$ TPI-14Met $\rightarrow$ Val mRNA does not reach low levels comparable to those of the controls for full NMD response: $\beta 39, \beta 39 / \mathrm{TPI}$, and $\beta 39 \mathrm{TPI}-14 \mathrm{Met} \rightarrow \mathrm{Val}$ mRNAs (Fig. 5B). Therefore, while NMD inhibition can be partially attributed to translation reinitiation, as previously shown by Zhang and Maquat (1997), our data demonstrate that the presence of a short ORF is independently sufficient to circumvent NMD. Although we cannot completely rule out that translation reinitiation may occur at another downstream AUG, namely, at codon 82, which is the next putative reinitiation codon that would inhibit NMD, this hypothesis seems unlikely based on results described by Zhang and Maquat (1997).

The above-mentioned conclusions were further tested in the context of the native TPI transcript (Fig. 6). Our results show that TPI mRNA carrying a nonsense mutation at codon 71 (TPI71 mRNA) is expressed at $\sim 10 \%$ of normal, demonstrating that it is fully committed to NMD. However, if the nonsense codon is moved to an AUG-proximal location at codon 10, the corresponding mRNA (TPI10 mRNA) accumulates at $\sim 92 \%$ of normal TPI. This NMD resistance is consistent with prior results (Zhang and Maquat 1997). By analyzing the mRNA TPI sequence, it is observed that downstream from codon 10 of the TPI mRNA, there are several putative reinitiation AUG codons. While the AUG at codons 14, 82, and 190/191 (located at 586, 382, and $56 \mathrm{nt}$ upstream of the last exon-exon junction, respectively) would allow the ribosome to extend far enough to displace all downstream EJCs and block NMD, the studies of Zhang and Maquat (1997) indicate that there are no effective reinitiation sites downstream from the 14Met codon. Based on these data, we studied the effect of blocking translation reinitiation at codon 14 on the TPI10 mRNA (TPI10-14Met $\rightarrow$ Val construct) (Fig. 6). Results show that expression of the TPI10$14 \mathrm{Met} \rightarrow$ Val mRNA is decreased to $75 \%$ of wild-type TPI mRNA, while normal TPI transcript 

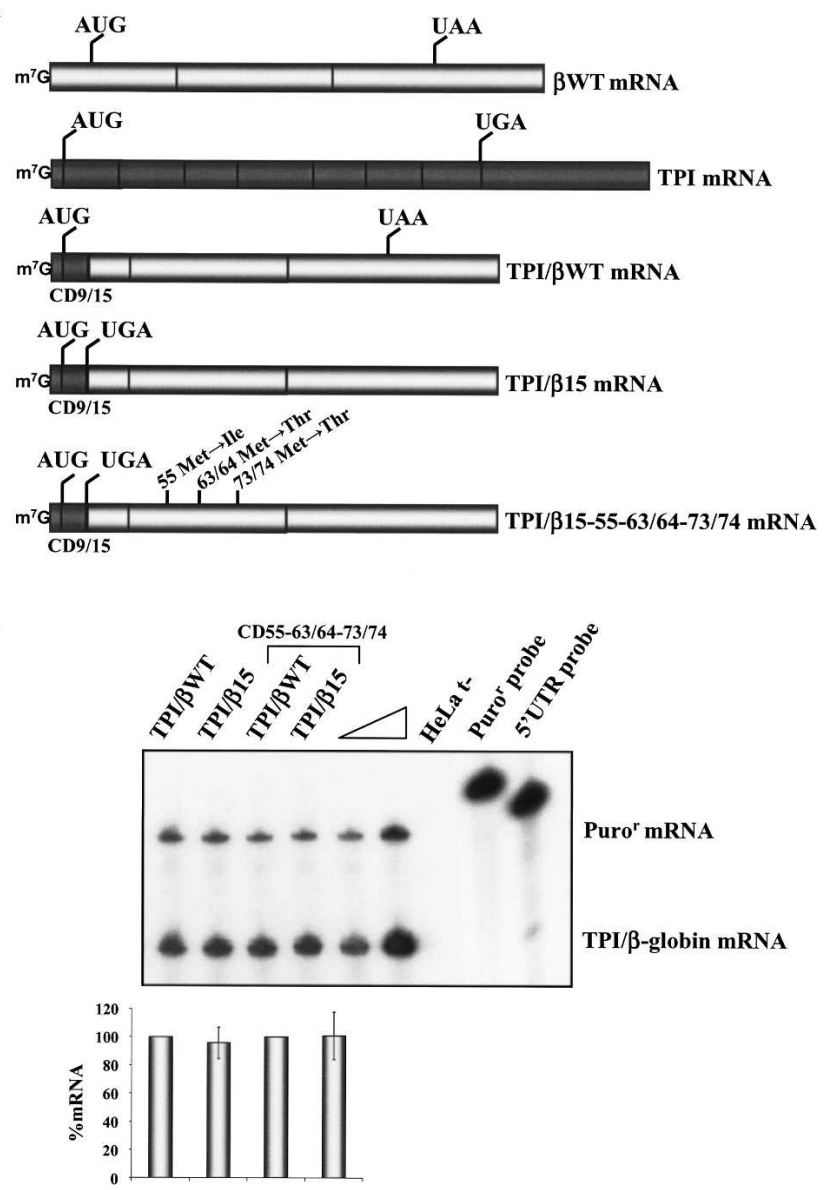

FIGURE 4. Human $\beta 15$ globin mRNA carrying the first nine-codon TPI ORF is resistant to NMD. (A) Physical maps of the hybrid TPI/ $\beta$ globin constructs. The bright rectangles represent $\beta$-globin exons, and dark rectangles represent TPI exons. CD9/15 represents the position of the junction between the TPI and $\beta$-globin genes. The position of initiation and termination (premature or native) codons is indicated. The name of each transcript is indicated to the right. (B) HeLa cells were transfected with the constructs specified above each lane [the plasmid also contains the puromycin-resistance $\left(\right.$ Puro $\left.^{r}\right)$ gene]. Total RNA was isolated and analyzed by RPA. The levels of each nonsensemutated TPI/ $\beta$-globin mRNA were quantified relatively to the Puro ${ }^{r}$ mRNA and normalized to the expression level of the corresponding nonsense-free gene. Increasing amounts of RNA (indicated by a triangle) from HeLa cells transfected with a TPI/ $\beta$ WT gene were also analyzed to demonstrate that the experimental RPA was carried out in probe excess; the amount of each of the input riboprobes used per analysis is also shown. The percentage mRNA values were plotted for each construct, and standard deviations from three independent experiments are shown.

levels are unaffected by the same missense mutation (TPI$14 \mathrm{Met} \rightarrow$ Val mRNA). Thus, inhibition of translation reinitiation at codon 14 fails to fully commit TPI10 mRNA to NMD, as the AUG-proximity effect is acting in parallel. In this respect, our results differ from a previous analysis of TPI NMD by Zhang and Maquat (1997). These authors reported a decrease in the expression level of nonsense TPI10, from $82 \%$ to $45 \%$ of normal, when translation reinitiation at codon
14 is blocked. Although puzzling, this discrepancy may reflect differences in the experimental settings: variations in NMD proficiency within the two cellular systems (HeLa cells versus mouse L cells) or deviations inherent to the different quantification methodologies, for example, in this study, the control for both transfection efficiency and RNA loading was an independent transcriptional unit, present in the plasmid carrying the test gene, whereas Zhang and Maquat (1997) used a cotransfected transgene.

\section{DISCUSSION}

Nonsense codons that are located $>50-54$ nt $5^{\prime}$ to an exonexon junction generally elicit NMD. We have previously

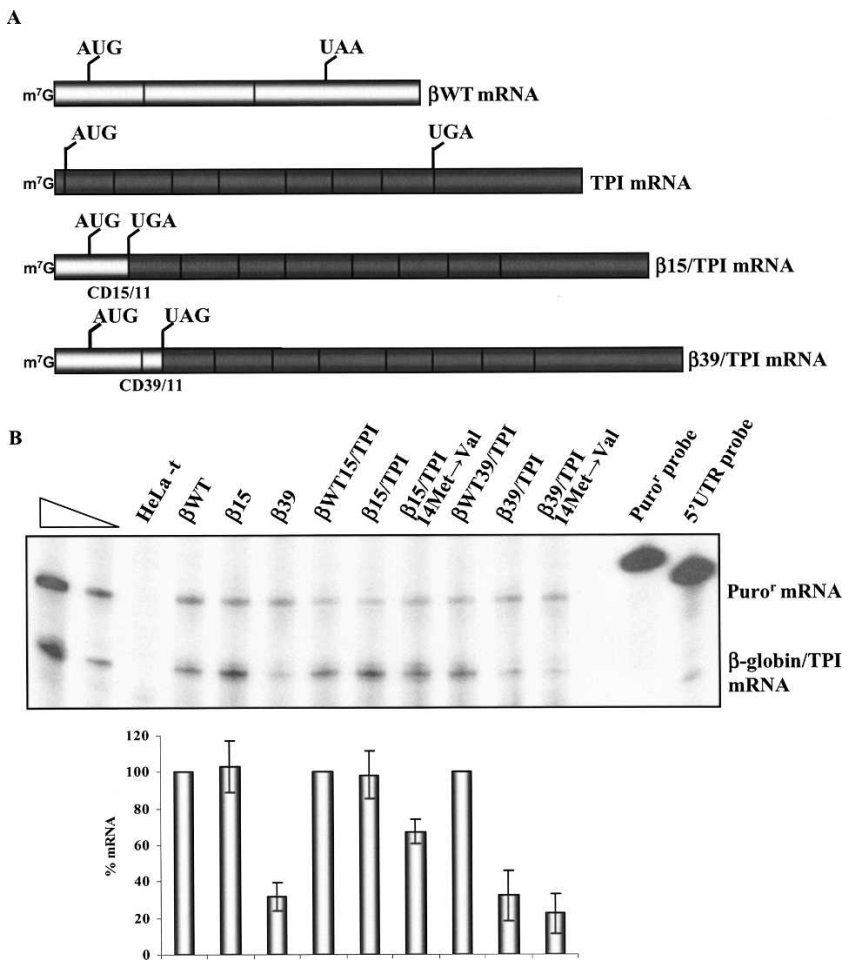

FIGURE 5. Human TPI mRNA carrying the first 15 codons of the $\beta 15$ globin ORF escapes NMD. (A) Physical maps of the hybrid $\beta$-globin/TPI mRNAs. The bright rectangles depict $\beta$-globin exons, and dark rectangles depict TPI exons. CD15/11 and CD39/11 indicate the junction position between the $\beta$-globin and TPI genes. The vertical lines represent the initiation and termination (native or premature) codons. The identification of each mRNA is indicated to the right. (B) HeLa cells were transfected with the constructs specified above each lane [the plasmid also contains the puromycinresistance $\left(\right.$ Puro $\left.^{\mathrm{r}}\right)$ gene]. Total RNA was isolated and analyzed by RPA. Levels of each nonsense-mutated $\beta$-globin/TPI mRNA were quantified relative to the Puro ${ }^{\mathrm{r}}$ mRNA and normalized to the expression level of the corresponding nonsense-free gene. Increasing amounts of RNA (indicated by a triangle) from HeLa cells transfected with a $\beta W T$ gene were also analyzed to demonstrate that the experimental RPA was carried out in probe excess; the amount of each of the input riboprobes used per analysis is also shown. The percentage mRNA values were plotted for each construct, and standard deviations from three independent experiments are shown. 

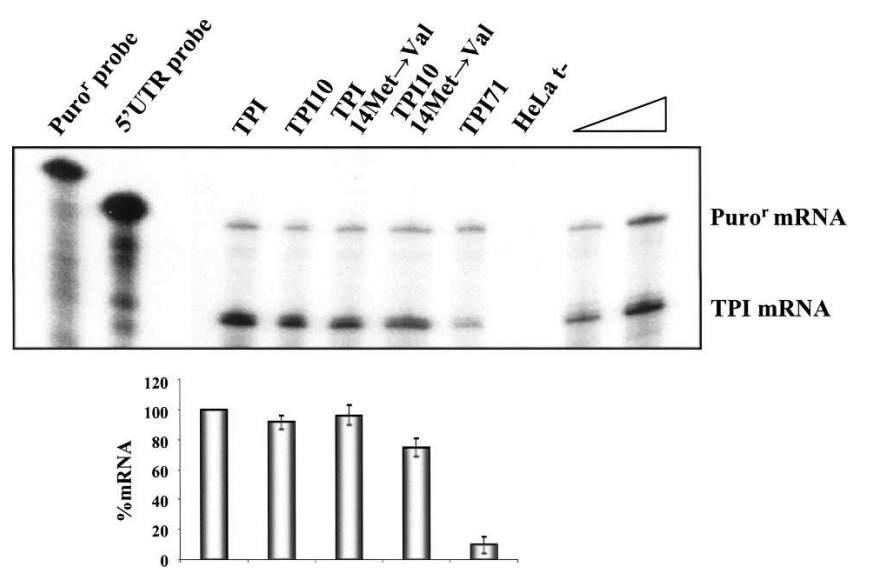

FIGURE 6. TPI transcripts bearing a short ORF escape NMD. HeLa cells were transfected with the constructs specified above each lane [the plasmid also contains the puromycin-resistance (Puro ${ }^{r}$ ) gene]. Total RNA was isolated and analyzed by RPA. Levels of each TPI mRNA were quantified relative to the Puro ${ }^{r}$ mRNA and normalized to the expression level of the wild-type TPI mRNA. Increasing amounts of RNA (indicated by a triangle) from HeLa cells transfected with a normal TPI gene were also analyzed to demonstrate that the experimental RPA was carried out in probe excess; the amount of each of the input riboprobes used per analysis is also shown. The percentage mRNA values relative to normal were plotted for each construct, and standard deviations from three independent experiments are shown.

reported that human $\beta$-globin mRNAs bearing nonsense mutations in the $5^{\prime}$ region of exon 1 accumulate to levels similar to those of wild-type $\beta$-globin mRNA (Romão et al. 2000). Functional analyses of these mRNAs with $5^{\prime}$ proximal nonsense mutations demonstrated that their resistance to NMD does not reflect translation reinitiation. Moreover, NMD inhibition is independent of promoter identity and erythroid specificity, and it is not a result of abnormal RNA splicing or impaired translation. In fact, analysis of the polysome profile of AUG-proximal nonsense mRNAs revealed their association with 1-1.5 ribosomes (Inácio et al. 2004). These studies demonstrated that the AUG-proximity of the nonsense codon may comprise the basis of the NMD resistance, overriding the "50-54-nt boundary rule" in establishing the overall efficiency of NMD. In this study, we confirm in an independent sequence context that the length of a translated ORF modulates NMD efficiency and extend our conclusions by demonstrating that the NMD inhibition is, in fact, ruled by the proximity of the nonsense codon to the AUG, rather than the distance to a putative $5^{\prime}$-UTR determinant. The presence of a short ORF on a given mRNA inhibits the canonical UPF1-dependent NMD, and this inhibition is independent of the transcript sequence context. While our results show that AUG proximity is a major determinant of the NMD effect, the data also indicate that it operates in parallel with other modifying influences. Specifically, translation reinitiation $3^{\prime}$ to the shortened ORF may contribute to alleviation of the NMD effect. These two parameters can independently contribute to the net overall NMD sensitivity of a nonsense-containing mRNA.

Knowing that NMD is translation dependent, the present data may suggest that the observed NMD resistance of mRNAs with a short ORF resulting from a nonsense codon could reflect ineffective translation. In this context, it is interesting to note that the smallest naturally occurring eukaryotic ORF that produces significant levels of protein product comprises 24 codons (Yu and Warner 2001). We have described a set of human $\beta$-globin gene nonsense mutations at codons 5,15 , and 17 that are not committed to NMD (Romão et al. 2000). On the other hand, a nonsense codon at position $21 / 22$, resulting from a $\beta$-thalassemic frameshift mutation, effectively elicits NMD (Zhang et al. 1998). Therefore, our results and those published by Zhang et al. (1998) suggest that for human $\beta$-globin mRNAs, the boundary between the $3^{\prime}$-most mutation that fails to trigger full NMD and the $5^{\prime}$-most mutation able to fully commit mRNA to the NMD pathway maps between codons 17 and 21/22 (Zhang et al. 1998; Romão et al. 2000). These data, when combined with data in the present report, allow us to conclude that mRNAs carrying nonsense mutations that create ORFs shorter than 18-20 codons may be NMD resistant, independent of the sequence background. The apparent concordance between the minimal length of an ORF for effective protein synthesis and the minimal length for effective NMD suggests that the cell may not require a quality-control mechanism to clear inefficiently translated mRNAs that encode relatively short peptide fragments.

It has been shown that nonsense surveillance contributes to the regulation of mRNAs containing uORF(s) (Mendell et al. 2004; Whittmann et al. 2006). However, it should be noted that, in general, the analyzed transcripts that were proposed to be naturally NMD-regulated seem to contain at least one uORF $>20$ codons. Thus, based on our results, it is possible to hypothesize that only those transcripts with at least one uORF containing $>20$ codons are NMD targets, and those naturally occurring with the $\mathrm{uORF}(\mathrm{s})$ smaller than $\sim 20$ codons could be NMD resistant.

The mechanisms of the observed NMD resistance of mRNAs with AUG-proximal nonsense codons and corresponding short ORFs may relate to critical aspects of the translational machinery. The short ORF may result in a temporal overlap between translational initiation and termination. The ribosome may arrive at the premature termination (nonsense) codon before it has had time to discharge its initiation factors and/or stabilize its interactions with elongation/termination factors. This might result in interference with elongation/termination reactions that may be central to the NMD pathway. Present evidence specifically identifies functional linkages between the translation termination process and the NMD pathway. Studies by others have revealed that during the process of translation of short upstream ORFs, interactions involving ribosomal or ribosome-associated factors, including, but 
not limited to releasing factors, can inhibit translation elongation as well as termination (Morris and Geballe 2000; Janzen et al. 2002). In the case of NMD, UPF1 must interact with eRF1 and eRF3 to terminate translation and, in the proper setting, to interact with additional factors to trigger NMD (Gaba et al. 2005; Kashima et al. 2006). Therefore, it is possible that the dynamics of the mRNP remodeling necessary for NMD cannot occur, or is defective, in this compressed environment of the mRNAs carrying a short ORF. This study illustrates that NMD may be modulated by the way a short ORF is translated.

\section{MATERIALS AND METHODS}

\section{Construction of expression vectors}

The wild-type $\beta$-globin gene ( $\beta \mathrm{WT}$ ), as well as the previously described human $\beta$-globin variants $\beta 15, \beta 39$, and $\beta 15(15: 39)$ (Inácio et al. 2004), were subcloned into the ClaI/ BspLU11I sites of the pTRE2pur vector (BD Biosciences) by PCR amplification of the 1806-bp ClaI/BspLU11I fragment, using primers with linkers for ClaI and BspLU11I (primers \#1 and \#2; Table 1). The $\beta$ WTins5'UTR, $\beta$ 15ins5'UTR, and $\beta 39$ ins5'UTR constructs were made by inserting the HindIII/ApaI fragment from $\beta 15$ (15:39) into the HindIII/ApaI restriction sites, which were previously created at $21 \mathrm{bp}$ upstream of the ATG codon of $\beta$ WT, $\beta 15$, and $\beta 39$ constructs, using the QuikChange Site-Directed Mutagenesis Kit (Stratagene), with mutagenic primers \#3 and \#4 (Table 1), as indicated by the manufacturer.

The 1677-bp EcoRI/RcaI fragment containing the whole wild-type $\alpha_{2}$-globin gene was obtained from plasmid pTet- $\alpha$ WT (Kong et al. 2003) and subcloned into EcoRI/BspLU11I sites of the pTRE2pur vector, originating the pTRE- $\alpha$ WT plasmid. Constructs $\alpha 4, \alpha 14$, $\alpha 16$, and $\alpha 40$, carrying nonsense mutations at codon positions 4 (CCT $\rightarrow$ TAG), 14 $(\mathrm{TGG} \rightarrow \mathrm{TAG}), 16(\mathrm{AAG} \rightarrow \mathrm{TAA})$, and 40 $(\mathrm{AAG} \rightarrow \mathrm{TAG})$, respectively, were created by site-directed mutagenesis, with mutagenic primers \#5-\#12 (Table 1), using the plasmid pTRE- $\alpha W T$ as DNA template. Potential reinitiation sites in $\alpha$-globin codons 32 and 76 were sequentially mutated in cis by sitedirected mutagenesis with primers \#13-\#16 (Table 1), using pTRE- $\alpha$ WT, $\alpha 14$, or $\alpha 40$ as template, creating the constructs $\alpha \mathrm{WT}-32$ $76 \mathrm{Met} \rightarrow \mathrm{Thr}, \quad \alpha 14-32-76 \mathrm{Met} \rightarrow \mathrm{Thr}, \quad$ and $\alpha 40-32-76 \mathrm{Met} \rightarrow \mathrm{Thr}$.

The human TPI gene sequence from 39 bp upstream of the initiation codon to 720 bp downstream from the stop codon was amplified by PCR, from plasmid pMT-TPI (Zhang and Maquat 1997), using primers with linkers for ClaI and BspLU11I (primers \#17 and \#18; Table 1), and inserted into pTRE2pur ClaI/BspLU11I sites. This construct was used as the parental vector for the TPI10, TPI10-14Met $\rightarrow$ Val, TPI-14Met $\rightarrow$ Val and TPI71 mutants, which were originated by site-directed mutagenesis as previously described, using primers \#19-\#24 (Table 1).

The hybrid genes $\beta$ WT15/TPI, $\beta 15 /$ TPI, $\beta$ WT39/TPI, and $\beta 39 /$ TPI were created by subcloning $\beta$-globin fragments amplified from the corresponding pTRE2pur $\beta$-globin variants, using specific
TABLE 1. DNA oligonucleotides used in the cloning strategies

\begin{tabular}{|c|c|}
\hline Primer & Sequence $\left(5^{\prime} \rightarrow 3^{\prime}\right)$ \\
\hline$\# 1$ & CCATCGATACATTTGCTTCTGACACAACTG \\
\hline$\# 2$ & TTACATGTAGGGATGGGCATAGGCATC \\
\hline$\# 3$ & САСАAСТGTGTTCACAAGCTTGGGСССТAGCAАССТCAAACAG \\
\hline$\# 4$ & CTGTTTGAGGTTGCTAGGGCCCAAGCTTGTGAACACAGTTGTG \\
\hline \#5 & GACGTTGGTCTTGTCGGCСTAAGACAGCACCATGGTGGG \\
\hline \#6 & СССАССАTGGTGСТGTCTTAGGCCGACAAGACCAACGTC \\
\hline$\# 7$ & GTGCGCGCCGACCTTACCCTAGGCGGCCTTGACGTTG \\
\hline \#8 & CAACGTCAAGGCCGCCTAGGGTAAGGTCGGCGCGCAC \\
\hline \#9 & CAGCGTGCGCGCCGACTTAACCCCAGGCGGCCTTGAG \\
\hline$\# 10$ & GTCAAGGCCGCCTGGGGTTAAGTCGGCGCGCACGCTG \\
\hline$\# 11$ & GAAGTGCGGGAAGTAGGTCTAGGTGGTGGGGAAGGACAG \\
\hline \#12 & СТGТССТТССССАССАССТАGАССТАСТТСССGСАСТТС \\
\hline$\# 13$ & GAAGGACAGGAACGTCCTGCGGGGAG \\
\hline$\# 14$ & СTCССCGCAGGACGTTCCTGTCСTTC \\
\hline$\# 15$ & AGCGCGTTGGGCGTGTCGTCCACG \\
\hline$\# 16$ & CGTGGACGACACGCCCAACGCGCT \\
\hline$\# 17$ & CCATCGATCGCGCAGACACTGACCTTCAGC \\
\hline$\# 18$ & ATTTTGTACACTGAAAGCTGGTGAGGCT \\
\hline$\# 19$ & TTCTTCGTTGGGTGAAACTGGAAGA \\
\hline$\# 20$ & TCTTCCAGTTTCACCCAACGAAGAA \\
\hline$\# 21$ & AACTGGAAGGTTAACGGGCGGAAGC \\
\hline$\# 22$ & GCTTCCGCCСGTTAACСTTCСАСТT \\
\hline$\# 23$ & AАCTGCTACAAAGTGACTTAGGGGGCTTTTACTGGGGAG \\
\hline$\# 24$ & CTCCСCAGTAAAAGCCССCTAAGTCACTTTGTAGCAGTT \\
\hline$\# 25$ & CCATCGATACATTTGCTTCTGACACAACTG \\
\hline$\# 26$ & TTTGATATCCCACAGGGCAGTAACGGCAGA \\
\hline$\# 27$ & TTTGATATCTCACAGGGCAGTAACGGCAG \\
\hline$\# 28$ & TTTGATATCCTGGGTCCAAGGGTAGACC \\
\hline$\# 29$ & TTTGATATCCTAGGTCCAAGGGTAGACC \\
\hline$\# 30$ & AGTTCTTCGTTGGGGGAGATATCAACTGGAAGATGAACGG \\
\hline$\# 31$ & ССGTTCATCTTCСАGTTGATATCTСССССАACGAAGAАСT \\
\hline$\# 32$ & GTTACTGCССTGTGGAACTGGAAGATGAACG \\
\hline$\# 33$ & CGTTCATCTTCCAGTTCCACAGGGCAGTAAC \\
\hline \#34 & GTTACTGCССTGTGAAACTGGAAGATGAACG \\
\hline \#35 & CGTTCATCTTCCAGTTTCACAGGGCAGTAAC \\
\hline$\# 36$ & TACCCTTGGACCCAGAACTGGAAGATGAAC \\
\hline$\# 37$ & GTTCATCTTCCAGTTCTGGGTCCAAGGGTA \\
\hline$\# 38$ & TACCCTTGGACCTAGAACTGGAAGATGAAC \\
\hline$\# 39$ & GTTCATCTTCCAGTTCTAGGTCCAAGGGTA \\
\hline$\# 40$ & СGTTCACСТTGССССАСССАACGAAGAАСТTCC \\
\hline$\# 41$ & CGTTCACCTTGССТCACCCAACGAAGAACTTCC \\
\hline \#42 & GGACTCAAAGAACСТСТGСССАACGAAGAACTTCC \\
\hline \#43 & GGACTCAAAGAACСТСТАСССАACGAAGAАСТTCC \\
\hline$\# 44$ & GGAAGTTCTTCGTTGGGTGGGGCAAGGTGAACG \\
\hline$\# 45$ & GGAAGTTCTTCGTTGGGTGAGGCAAGGTGAACG \\
\hline \#46 & GGAAGTTCTTCGTTGGGCAGAGGTTCTTTGAGTCC \\
\hline \#47 & GGAAGTTCTTCGTTGGGTAGAGGTTCTTTGAGTCC \\
\hline
\end{tabular}


primers with ClaI and EcoRV linkers (primers \#25-\#29; Table 1). These fragments were inserted into the ClaI/EcoRV sites of the pTRE2purTPI construct (the EcoRV site was previously inserted into this original construct between TPI codons 10 and 11 by sitedirected mutagenesis with primers \#30 and \#31) (Table 1). Then, this EcoRV site was deleted from the finished constructs using the same procedure with primers \#32-\#39 (Table 1). In addition, $\beta 15 /$ TPI as well as $\beta 39 /$ TPI constructs were used to introduce the missense mutation $($ ATG $\rightarrow$ GTT) at codon 14 of TPI by site-directed mutagenesis using specific primers \#21 and \#22 (Table 1), originating the constructs $\beta 15 / \mathrm{TPI}-14 \mathrm{Met} \rightarrow \mathrm{Val}$ and $\beta 39 / \mathrm{TPI}-$ $14 \mathrm{Met} \rightarrow$ Val.

The hybrid genes TPI/ $\beta$ WT and TPI/ $\beta 15$ were created by overlapping PCR using primers \#2, \#17, and \#40-\#47 (Table 1) to fuse the TPI $5^{\prime}$-UTR and the first 10 codons containing fragments of the $\beta$-globin gene sequence from codon 16 to the $3^{\prime}$ UTR. The putative reinitiation codons at codons 55 (ATG $\rightarrow$ ATA), $63 / 64(\mathrm{ATG} \rightarrow \mathrm{ACG})$, and $73 / 74(\mathrm{ATG} \rightarrow \mathrm{ACG})$ of these hybrid genes were mutated as previously described in Inácio et al. (2004) originating TPI/ $\beta W T-55-63 / 64-73 / 74$ and TPI/ $\beta 15-55-63 / 64-73 /$ 74 constructs.

\section{Cell culture and transfection}

HeLa cells, stably expressing the tet transactivator (HeLa/tTA) (described by Kong et al. 2003), were grown in Dulbecco's modified Eagle's medium (DMEM) supplemented with $10 \%$ fetal bovine serum. Transient transfections were performed using Lipofectamine 2000 Transfection Reagent (Invitrogen), following the manufacturer's instructions, in 35-mm plates using $250 \mathrm{ng}$ of the test construct DNA and $1750 \mathrm{ng}$ of pEGFP vector (BD Biosciences) DNA as a control for transfection efficiency. Cells were harvested after a 20-h transcription pulse.

Mouse erythroleukemia (MEL) cells stably expressing the tet transactivator (MEL/tTA) (Kong et al. 2003) were used for conditional expression of human $\alpha$-globin genes (previously cloned into the pTRE2pur vector). For transient transfections, $\mathrm{MEL} / \mathrm{tTA}$ cells were split $1 \mathrm{~d}$ before transfection and cultured in minimal essential medium (MEM) supplemented with $10 \%$ fetal bovine serum, and $100 \mathrm{ng} / \mathrm{mL}$ tetracycline. Cells were transfected with $2 \mu \mathrm{g}$ of pTRE- $\alpha \mathrm{WT}$, or each variant, along with $18 \mu \mathrm{g}$ of carrier DNA, as previously described. After an overnight recovery in $\mathrm{Tet}^{+}$medium, cells were split into 60 -mm-diameter dishes, and pulsed with $\alpha$-globin mRNA for $4 \mathrm{~h}$ by growth in Tet $^{-}$media. Following this period, transcription from the plasmid was blocked by the addition of Tet to the media. Cells from each culture dish were harvested at different time points for further analysis.

\section{Transient transfection of siRNA}

Transient transfections of siRNAs were carried out using Lipofectamine 2000 reagent (Invitrogen) according to the manufacturer's instructions in $35-\mathrm{mm}$ plates using $100 \mathrm{pmol}$ of siRNA oligonucleotides and $4 \mu \mathrm{L}$ of transfection reagent. Twenty-four hours later, cells were transfected again with 50 pmol of siRNAs, $250 \mathrm{ng}$ of the test construct DNA, and $1000 \mathrm{ng}$ of pEGFP vector. Twenty-four hours later, cells were harvested for analysis of RNA and protein expression. The siRNA oligonucleotides used for transfections [Luciferase (AA-CGUACGCGGAAUACUUCGA) and hUPF1 (AA-GAUGCAGUUCCGCUCCAUU)] were purchased as annealed, ready-to-use duplexes from Dharmacon.

\section{RNA isolation}

Total RNA from transfected cells was prepared using the RNeasy minikit (QIAGEN) following the manufacturer's indications. RNA samples were treated with RNase-free DNase I (Ambion) and purified by phenol:chloroform extraction. Before further analyses, mRNA samples were tested by RT-PCR to reject the hypothesis of activation of cryptic splicing pathway(s), with consequent alteration in mRNA sequence and possible circumvention of the premature termination codon. From all transcript species a single full-length product was amplified (data not shown), demonstrating that the studied nonsense transcripts present a normal splicing pattern.

\section{Ribonuclease protection assays (RPA)}

The probes used were generated by in vitro transcription, using a Maxiscript T7 kit (Ambion), under conditions recommended by the manufacturer. The $5^{\prime}$-UTR probe is the 180 -bp StuI/HindIII fragment of pTRE2pur inserted into HindIII/EcoRV sites of pcDNA3 (Invitrogen) that protects the $150 \mathrm{nt}$ of the $5^{\prime}$ part of the $5^{\prime}$-UTR common to all genes cloned into the pTRE2pur ClaI site. The $\alpha$-globin probe is a 174-bp fragment encompassing the $3^{\prime}$ part of exon 3 inserted into the polylinker region of pTRI-amp-18 (Ambion). The Puro ${ }^{r}$ probe is a 280-bp puromycin-resistance gene fragment cloned into pGEM-3 (Promega) and protects a 197-nt sequence of the puromycinresistance mRNA. The $\alpha$-globin probe for half-life analysis is a 244nt fragment protecting the 132-nt exon 1. The murine GAPDH probe protects a 316-nt fragment (Ambion) (Kong et al. 2003). Samples were processed as described in Inácio et al. (2004).

\section{Western blot analysis}

Protein lysates were resolved, according to standard protocols, in $10 \%$ or $14 \%$ SDS-PAGE for hUPF1, or $\beta$-globin detection, respectively, and transferred to PVDF membranes (Bio-Rad). Membranes were probed using mouse monoclonal anti- $\alpha$-tubulin (Roche) at 1:10000 dilution and goat polyclonal anti-hUPF1 (Bethyl Labs) at 1:500 dilution or rabbit polyclonal anti-h $\beta$-globin (Cappel) at 1:1000 dilution. Detection was carried out using secondary peroxidaseconjugated anti-mouse IgG (Bio-Rad), anti-rabbit IgG (Bio-Rad), or anti-goat IgG (Sigma) antibodies followed by chemiluminescence.

\section{ACKNOWLEDGMENTS}

We thank Lynne Maquat for a plasmid carrying the human TPI gene. This work was partially supported by Fundação para a Ciência e a Tecnologia (POCTI/MGI/48296/2002, POCTI/ SAU-MMO/57573/2004 and Programa Plurianual/CIGMH) and Programa Operacional de Saúde-Saúde XXI. A.L.S., F.J.C.P., A.M., and R.M. were supported by fellowships from Fundação para a Ciência e a Tecnologia. Funding was also made available from NIH grant R37-HL 65449-MERIT (to S.A.L.).

Received June 20, 2006; accepted September 20, 2006. 


\section{REFERENCES}

Fribourg, S., Gatfield, D., Izaurralde, E., and Conti, E. 2003. A novel mode of RBD-protein recognition in the Y14-Mago complex. Nat. Struct. Biol. 10: 433-439.

Gaba, A., Jacobson, A., and Sachs, M.S. 2005. Ribosome occupancy of the yeast CPAl upstream open reading frame termination codon modulates nonsense-mediated mRNA decay. Mol. Cell 20: 449460.

Gehring, N.H., Neu-Yilik, G., Schell, T., Hentze, M.W., and Kulozik, A.E. 2003. Y14 and hUpf3b form an NMD-activating complex. Mol. Cell 11: 939-949.

Ghilardi, N. and Skoda, R.C. 1999. A single-base deletion in the thrombopoietin (TPO) gene causes familial essential thrombocythemia through a mechanism of more efficient translation of TPO mRNA. Blood 94: 1480-1482.

Inácio, A., Silva, A.L., Pinto, J., Ji, X., Morgado, A., Almeida, F., Faustino, P., Lavinha, J., Liebhaber, S.A., and Romão, L. 2004. Nonsense mutations in close proximity to the initiation codon fail to trigger full nonsense-mediated mRNA decay. J. Biol. Chem. 279: 32170-32180.

Ishigaki, Y., Li, X., Serin, G., and Maquat, L.E. 2001. Evidence for a pioneer round of mRNA translation: mRNAs subject to nonsense-mediated decay in mammalian cells are bound by CBP 80 and CBP20. Cell 106: 607-617.

Janzen, D.M., Frolova, L., and Geballe, A.P. 2002. Inhibition of translation termination mediated by an interaction of eukaryotic release factorl with a nascent peptidyl-tRNA. Mol. Cell. Biol. 22: $8562-8570$.

Kashima, I., Yamashita, A., Izumi, N., Kataoka, N., Morishita, R., Hoshino, S., Ohno, M., Dreyfuss, G., and Ohno, S. 2006. Binding of a novel SMG-1-Upf1-eRF1-eRF3 complex (SURF) to the exon junction complex triggers Upf1 phosphorylation and nonsensemediated mRNA decay. Genes \& Dev. 20: 355-367.

Kong, J., Ji, X., and Liebhaber, S.A. 2003. The KH-domain protein $\alpha \mathrm{CP}$ has a direct role in mRNA stabilization independent of its cognate binding site. Mol. Cell. Biol. 23: 1125-1134.

Kunz, J.B., Neu-Yilik, G., Hentze, M.W., Kulozik, A.E., and Gehring, N.H. 2006. Functions of hUpf3a and hUpf3b in nonsense-mediated mRNA decay and translation. RNA 12: 1-8.

Lau, C.K., Diem, M.D., Dreyfuss, G., and Van Duyne, G.D. 2003. Structure of the Y14-Magoh core of the exon junction complex. Curr. Biol. 13: 933-941.

Le Hir, H., Izaurralde, E., Maquat, L.E., and Moore, M.J. 2000. The spliceosome deposits multiple proteins 20-24 nucleotides upstream of mRNA exon-exon junctions. EMBO J. 19: 6860-6869.

Le Hir, H., Gatfield, D., Izaurralde, E., and Moore, M.J. 2001. The exon-exon junction complex provides a binding platform for factors involved in mRNA export and nonsense-mediated mRNA decay. EMBO J. 20: 4987-4997.

Lejeune, F. and Maquat, L.E. 2005. Mechanistic links between nonsense-mediated mRNA decay and pre-mRNA splicing in mammalian cells. Curr. Opin. Cell Biol. 17: 309-315.
Lejeune, F., Ishigaki, Y., Li, X., and Maquat, L.E. 2002. The exon junction complex is detected on CBP80-bound but not eIF4Ebound mRNA in mammalian cells: Dynamics of mRNP remodeling. EMBO J. 21: 3536-3545.

Maquat, L.E. 2004. Nonsense-mediated mRNA decay: Splicing, translation and mRNP dynamics. Nat. Rev. Mol. Cell Biol. 5: 89-99.

Maquat, L.E. 2005. Nonsense-mediated mRNA decay in mammals. J. Cell Sci. 118: 419-422.

Mendell, J.T., ap Rhys, C.M., and Dietz, H.C. 2002. Separable roles for rent1/hUpf1 in altered splicing and decay of nonsense transcripts. Science 298: 419-422.

Mendell, J.T., Sharifi, N.A., Meyers, J.L., Martinez-Murillo, F., and Dietz, H.C. 2004. Nonsense surveillance regulates expression of diverse classes of mammalian transcripts and mutes genomic noise. Nat. Genet. 36: 1073-1078.

Morris, D.R. and Geballe, P. 2000. Upstream open reading frames as regulators of mRNA translation. Mol. Cell. Biol. 20: 8635-8642.

Pereira, F.J.C., Silva, M.C., Picanço, I., Seixas, M.T., Ferrão, A., Faustino, P., and Romão, L. 2006. Human $\alpha 2$-globin nonsensemediated mRNA decay induced by a novel $\alpha$-thalassaemia frameshift mutation at codon 22. Br. J. Haematol. 133: 98-102.

Poyry, T.A., Kaminski, A., and Jackson, R.J. 2004. What determines whether mammalian ribosomes resume scanning after translation of a short upstream open reading frame? Genes \& Dev. 18: 62-75.

Romão, L., Inácio, A., Santos, S., Ávila, M., Faustino, P., Pacheco, P., and Lavinha, J. 2000. Nonsense mutations in the human $\beta$-globin gene lead to unexpected levels of cytoplasmic mRNA accumulation. Blood 96: 2895-2901.

Stockklausner, C., Breit, S., Neu-Yilik, G., Echner, N., Hentze, M.W., Kulozik, A.E., and Gehring, N.H. 2006. The uORF-containing thrombopoietin mRNA escapes nonsense-mediated decay (NMD). Nucleic Acids Res. 34: 2355-2363.

Sun, X., Perlick, H.A., Dietz, H.C., and Maquat, L.E. 1998. A mutated human homologue to yeast Upf1 protein has a dominant-negative effect on the decay of nonsense-containing mRNAs in mammalian cells. Proc. Natl. Acad. Sci. 95: 10009-10014.

Thermann, R., Neu-Yilik, G., Deters, A., Frede, U., Wehr, K., Hagemeier, C., Hentze, M.W., and Kulozik, A.E. 1998. Binary specification of nonsense codons by splicing and cytoplasmic translation. EMBO J. 17: 3484-3494.

Wittmann, J., Hol, E.M., and Jack, H.-M. 2006. hUPF2 silencing identifies physiologic substrates of mammalian nonsense-mediated mRNA decay. Mol. Cell. Biol. 26: 1272-1287.

Yu, X. and Warner, J.R. 2001. Expression of a micro-protein. J. Biol. Chem. 276: 33821-33825.

Zhang, J. and Maquat, L.E. 1997. Evidence that translation re-initiation abrogates nonsense-mediated mRNA decay in mammalian cells. EMBO J. 16: 826-833.

Zhang, J., Sun, X., Qian, Y., and Maquat, L.E. 1998. Intron function in the nonsense-mediated decay of $\beta$-globin mRNA: Indications that pre-mRNA splicing in the nucleus can influence mRNA translation in the cytoplasm. RNA 4: 801-815. 

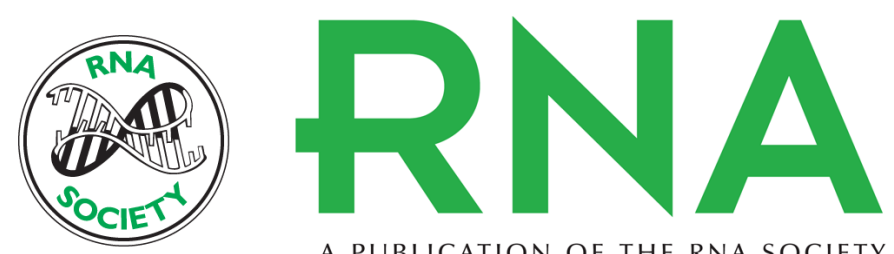

A PUBLICATION OF THE RNA SOCIETY

\section{The canonical UPF1-dependent nonsense-mediated mRNA decay is inhibited in transcripts carrying a short open reading frame independent of sequence context}

Ana Luísa Silva, Francisco J.C. Pereira, Ana Morgado, et al.

RNA 2006 12: 2160-2170 originally published online October 31, 2006

Access the most recent version at doi:10.1261/rna.201406

References This article cites 30 articles, 19 of which can be accessed free at:

http://rnajournal.cshlp.org/content/12/12/2160.full.html\#ref-list-1

License

Email Alerting Receive free email alerts when new articles cite this article - sign up in the box at the Service top right corner of the article or click here.

To subscribe to RNA go to:

http://rnajournal.cshlp.org/subscriptions 